\title{
Residential Security as Social Protection
}

\author{
Haris Gazdar and Hussain Bux Mallah
}

\begin{abstract}
This article argues that residential insecurity and social marginalisation are closely linked, particularly in communities where housing is accessed through traditional and patriarchal social institutions. It uses community histories from rural areas of the Sindh province in Pakistan to analyse the processes and impacts of a scheme for the regularisation of housing rights for the landless poor, with a special focus on mobilisation among the socially marginalised. Government schemes that require prior collective action on the part of beneficiaries can strengthen the process of political enfranchisement of groups already on an upward trajectory. On their own, however, such interventions can exclude the most marginalised who are too weak to organise collective action or to form themselves into effective groups. $A$ comprehensive social protection agenda, therefore, requires both types of interventions - those that ensure the inclusion of the marginalised in 'passive' transfers and those that create incentives and reward collective action.
\end{abstract}

\section{Transformative social protection and housing}

Transformative social protection must enable the effective realisation of citizenship rights, particularly in the economic sphere, not only through the passive offer of safety nets but through processes of active engagement (Devereux and Sabates-Wheeler 2004; Kabeer 2002, 2005). This can happen through two main routes. One is the provision of interventions that address the particular requirements of socially marginalised citizens. These interventions include affirmative action policies that increase participation of marginalised individuals and groups, and hence assist them in overcoming systematic disadvantages. For the most part, such schemes, even those where affirmative action is a key component, do not require collective action on the part of the socially marginalised. A second route is through the encouragement of agency and collective action among target individuals and groups in the very process of accessing the programme.

To the extent that marginalisation is understood as a process of segmentation, collective action is a counter process. It is presumed that once marginalised individuals and groups are engaged in collective action for a particular purpose they acquire the political resources for gaining access to a range of other citizenship-based entitlements (Sharma 1992). Seminal literature on collective action (Olson 1971) provides an account of the barriers to group formation. In much of South Asia, the problem is even more acute for those who are isolated from the mainstream on grounds of gender, caste, religion and ethnicity.

The conventional understanding of social protection - with a strong focus on social security and safety nets - is centred on individual citizens, or at most families. In a number of countries where affirmative action is an accepted institutional approach, social groups are recognised as targets of policy, but in most cases, the benefits are still aimed at individuals and families within the targeted groups. There are a number of diverse interventions, however, which are premised on group mobilisation for collective benefits. $^{1}$

Although land reforms have faded away from the policy discussion across South Asia, it is useful to recall that the early rationale for them was very close to the agenda of transformative social protection. Pakistan stands out in South Asia as a 
country where land reforms were less ambitious and remained on the political map only briefly. In one relatively unnoticed aspect of land reform, however, Pakistan's record might be less discouraging. While the debate is mostly focused on the agrarian economy, the provision of title or security of tenure over residential land appears to have been a more widespread intervention in terms of the number of beneficiaries.

This article focuses on the SGAHS (literally, Sindh village development and housing scheme), which was launched in 1987 to regularise rural settlements in the Sindh province of Pakistan. SGAHS qualifies, at least on the surface, as a transformative social protection intervention in a region beset by extreme class inequalities. It represents asset transfers to some of the poorest and most marginalised segments of the population, and is aimed at protecting the beneficiaries from residential insecurity as well as other forms of insecurity and vulnerability that are associated with it. The scheme has remained largely unnoticed, despite its high number of supposed beneficiaries compared with conventional land reform. While it has remained in a state of dormancy in recent years, the implementation of the SGAHS and its interaction with the poor and socially marginalised holds lessons for its potential revival and for other similar interventions.

Following a long period of relative neglect, there has been a revival of policy interest in Pakistan in social protection and asset transfers to the poor. The establishment of a large-scale targeted cash transfer programme (Benazir Income Support Programme or BISP) by the central government in 2008, and the initiation of a provincial government programme in Sindh for providing state land to the rural landless in the same year will offer potential points of comparison between 'passive', 'active' and 'mobilisational' social protection interventions. The BISP is a 'passive' transfer in the sense that beneficiary selection is based on an administratively generated register that includes all households. The 'pro-active' element in its design relates to the use of the census method to create the initial register. Both the BISP and the Sindh state land scheme have introduced affirmative action in beneficiary selection for the first time in Pakistan - through defining poor women as primary beneficiaries. Neither initiative, however, requires prior mobilisation or collective action on the part of potential beneficiaries.

This article uses community histories in selected rural areas of the Sindh province of Pakistan to answer the following questions:

- What is the relationship between residential security and social marginalisation, particularly in a society where access to resources is mediated through traditional and informal arrangements?

- What are the modes of collective action that the poor and the marginalised use in order to access a 'mobilisational' asset transfer scheme? Which groups benefit most, and who is left behind?

\section{Background and description of SGAHS}

Sindh is Pakistan's second largest province with a dual economy consisting of a highly developed urban centre (Karachi) and a mostly agrarian rural hinterland. Around 51 per cent of the province's 40 million people live in rural areas which are among the most underdeveloped and impoverished parts of the country. The economy of rural Sindh is highly dependent on canalbased irrigation, and is marked by highly unequal land ownership patterns.

Nearly two-thirds of all rural households do not own any agricultural land at all, and the top 1.5 per cent own around 37 per cent of the entire cropped area. ${ }^{3}$ Share-cropping has been an important though declining form of land tenure and has provided access to agricultural selfemployment to significant sections of the landless poor. The landlord-tenant relationship has been a central concern of political movements, social activists and policymakers. While successive attempts at land reform as well as economic and demographic changes have altered some of the contours of this system, its basic features remain the same.

Large area landlords are believed to dominate economic and political life in rural areas, and their domination is thought to be premised on their control over land and irrigation water. Laws for regulating this system in favour of the sharecropping tenants and protecting them from extreme human rights violations include the 
Tenancy Act (1951) and the Bonded Labour Abolition Act (1992). The landlords' control or ownership of residential land occupied by tenants and smallholders is thought to provide them with an important lever in their economic and political interactions, and thus as a source of exclusion and marginalisation of the landless.

Land inequality in Sindh does not imply the absence of contestation and change in land ownership. While conventional land reforms did not even attempt to address the scale of land inequality, there were nevertheless, major shifts in land ownership over the decades. Many of those regarded as large landlords today, are individuals or families who worked as tenant farmers until few decades ago. Political and criminal violence led to the displacement of entire groups of landowners by relative newcomers who in turn faced fresh challenges from below. Inequality has remained but there has been turnover in those who occupy the top rungs of the ownership ladder.

SGAHS was introduced in 1987 as an intervention for improving the physical conditions of villages and enhancing the tenancy status of existing residents. Its introduction immediately followed several years of intense and bloody political agitation in rural Sindh against an unpopular military government. The scheme and other interventions of the time were associated with the person of Prime Minister Mohammad Khan Junejo who was a transitional figure from direct military rule to civilian government. Class politics had gained prominence in the 1970s during the rule of the populist $\mathrm{PPP}^{4}$ when anti-landlord rhetoric had been buttressed by limited nominally prolandless and pro-tenant legislative measures. ${ }^{5}$ The Junejo interventions were seen as concessions to a restive population to wean it away from the PPP.

The scheme allowed villagers to apply for the regularisation of their villages. According to official data, over 11,000 villages have been regularised through this scheme, and individual leases have been allotted to over 700,000 beneficiary households, benefiting over 4 million people.

The scheme is based on two assumptions, which are implied rather than clearly stated. First, entire villages had insecure property rights to the land on which they were located. Second, the regularisation of tenancy rights of existing residents needed to precede or accompany the physical development of the village. The broader socioeconomic context implicit in the scheme's approach is that of an economy dominated by landlords, where landless share-cropping tenants did not enjoy secure rights over their homesteads.

The regularisation of a village requires a group of residents to make a formal application for regularisation to an official specifically appointed in the district land administration department to implement the SGAHS. The department is then responsible for ascertaining the land title and carrying out a detailed cadastral survey of the settlement. The SGAHS defines a village as a settlement comprising at least ten houses located within a reasonable distance from each other, and at least five kilometres away from the city centre. The application must include authenticated documents such as a physical survey map, a list of households, population, written consent of landowner if private land, a 'no-objection certificate' from the relevant landowning government department, and copies of the national identity cards of applicants, as well as other proof of continuous residence such as the electoral list.

If the land in question is state-owned, it is leased out to the applicants upon satisfactory completion of the administrative process. For privately owned land, SGAHS was authorised to acquire it against the payment of compensation to the owner. The conversion of private land was suspended in 1996 due to allegations of corrupt practices, although there has been discussion within the provincial government recently for its revival. ${ }^{6}$

Although SGAHS remains officially in operation, its activities have slowed down considerably since the mid-1990s. It is not clear if this lack of activity is due to a loss of administrative and political energy behind the scheme, or because of an absence of new demand from landless residents. There is clearly scope for further expanding the number of beneficiaries to cover anywhere between 15 and 45 per cent of the province's rural population.

There has been a revival of policy interest in land allotment and regularisation, in-keeping with 
which the provincial government announced a programme for the allotment of over 40,000 acres of state-owned land among landless women in 2008. The SGAHS also saw a rise in activity in the recent years in villages surrounding the main urban metropolis in Sindh (Karachi), where village land is being rapidly converted to urban residential and commercial use. Former rural communities on the outskirts of the city are using SGAHS in order to assert their property rights and then selling land at a high premium to property developers.

\section{Patterns of rural settlement in Sindh}

The smallest administrative unit of land in rural Sindh is called a deh. Although this term literally means 'village' in the administrative vocabulary in many parts of South Asia, in Sindh the deh is merely a unit of territorial jurisdiction of the land bureaucracy. Several dehs make up a Union Council, which is the smallest unit of political representation in local government. Actual human settlements, known as goths, are smaller entities which have only notional linkages with the deh. It is often but not always the case that the largest settlement in a deh will share its name with the deh. Actual villages or goths are often divided into sub-clusters called para, which are almost always populated by extended families belonging to one caste or kinship group. Smaller villages might consist of only one para.

The land within a deh is divided administratively into two main parts: cultivable and non-cultivable. Cultivable areas are generally owned by private individuals and held as freehold. Non-cultivable land is usually owned by the state even if it is in private use. No land revenue or irrigation charges are payable on non-cultivable land, which is marked as such on deh maps. These maps also identify recognised human settlements. Most actual settlements are located on non-cultivable state-owned land - known as bhadda - although there is no bar on individuals setting up homesteads on their own privately owned land, or making their land available to others, such as their tenants, for setting up their homesteads.

There are customary norms recognised by the land administration that govern access to bhadda land. Those who own cultivated area adjacent to bhadda - the local term for such proximity is mohaga - have the first right of use in the bhadda. Conventionally, this right of mohaga has been interpreted to mean the entitlement to set up a homestead, or to provide space for homestead to a tenant or other dependent. The right of mohaga is also used to convert non-cultivable state-owned land to a cultivable privately owned area in favour of the incumbent landowner.

The division of space within a settlement is strongly influenced by patriarchal social organisation. The para is composed of close relatives and there are no restrictions on the mobility of men and women belonging to a para within its confines. Para boundaries are often physically marked using thorn bushes, which divide private and public spaces. Adult women have limited access to public spaces outside the para, and adult men from outside the para or village are generally not allowed to enter the para.

An important institution in a para or a village is the autaq (male meeting place), where men from outside the para or village can be received, and where economic and political business including buying and selling of produce, the population census, the $\mathrm{BISP}^{7}$ poverty survey, microfinance group meetings - might be transacted between men. Women generally do not enter the autaq, and men from outside the village or para traditionally do not go beyond the autaq. The autaq might be a grand building or a modest shelter. Although it is privately owned, by convention all male residents of a village or para have access to it. In fact, the owner of an autaq actively encourages the use of the autaq as a meeting place as a means of acquiring political and social status.

\section{Insights from two survey sites 4.1 Deh Mori}

Deh Mori is a cluster of around 17 villages in the Shahdadpur Taluka (sub-district) of District Sanghar. Mori is rural and mostly agrarian, with high value wheat and cotton cultivation on canalirrigated land with a population of 3,000 in 2005. The largest village in the deh is also called Mori and has a population of around 1,000. It has a basic infrastructure, including a government school, a bus service, electricity and several small shops. Besides Mori village (MV) we focus attention on two other settlements in the deh: Omar Wasan (OW) and Ghullan Machhi (GM).

MV was regularised under SGAHS in the late 1980s. There is no clear recollection, locally, of 
the process of regularisation, how it was initiated or who pursued it. The SGAHS administration had deputed two government schoolteachers to visit the village and carry out a cadastral survey. They also listed the households and homestead land in their possession and prepared the documents necessary for processing the case. Residents did not pay much attention to this activity at the time, and assumed that nothing would come of it. Around 20 of the 100 or so households of MV lived on a landlord's private land adjacent to the village bhadda. They were not included in the survey and also did not approach the surveyors for inclusion. They were unaware that there was an option in the law for including privately owned land in the scheme. Those whose homesteads were surveyed received lease certificates in due course.

MV is divided into six para and two large autaqs belonging to absentee landlords. All residents of the village are either smallholders, nonlandowning share-croppers or wage labourers. The Duzkanis are the dominant group in village politics, although a majority of them too are landless. Other landless groups include Bheels (a Hindu scheduled caste), Ibupotas and Khaskhelis. These latter three are regarded as socially marginalised to different degrees, and they happen to be disproportionately represented among those who were left out of the SGAHS survey. Out of the 20 Bheel households of MV, for instance, eight were in the regularised part of the village while 12 were outside it. Over time, these two groups had diverged perceptively in terms of their housing conditions, children's schooling, skilled jobs, and political enfranchisement. These latter Bheels have cultivated strong ties with a powerful absentee landlord, and are now considered among leaders of the Bheel community in the area.

The land surrounding the settlement is owned by a number of absentee landlords and a local family known as the Sanjranis. Iqbal Sanjrani acquired land gradually over the decades from absentee landlords, and has close connections with a politically influential spiritual leader. Some of the Bheel families who live on Iqbal's land abutting the regularised part of the village work as his share-croppers, while others worked as casual labourers in and around the village. Facing a labour shortage for cotton harvesting last season (autumn 2009), Iqbal asserted that being the owner of their homestead land, he had the first right over the services of these Bheel labourers. The Bheels saw little option but to comply.

In 2005, Ahmad Duzkani decided to construct a kiosk on an unused plot of land adjacent to the village boundary. Iqbal Sanjrani claimed that this was an encroachment since the unused plot was on the mohaga of his cropped land. The two parties agreed to refer to the SGAHS survey, which showed that the Ahmad Duzkani's shop was well within the boundaries of the regularised village. Iqbal Sanjrani had to concede, and the Duzkanis felt that regularisation had empowered them to hold their ground. They noted that although they had not paid much attention to the SGAHS survey when it first happened, they were now grateful that they had a powerful tool to resist what they regarded as bullying on the part of Iqbal Sanjrani and his relatives.

OW village is dominated by Omar who owns the cropped area surrounding the settlement. Although the village is on state-owned bhadda land, Omar asserts virtual ownership rights over it. The original bhadda consisted of 24 acres, but over time, Omar has used his right of mohaga to get 16 acres converted into cultivable land in his own name. It is thought that he has also acquired a power of attorney over the remaining 8 acres on which homesteads stand. Until 2008, the settlement consisted of three extended Bheel share-croppers who claimed to have inhabited the village for several generations. The Bheels had suffered frequent verbal abuse as well as physical violence at the hands of Omar, and were finally evicted by him when they took up a sharecropping tenancy with another landowner.

The Bheels have set up homesteads on the land of their new landlord, Leghari. They feel isolated and vulnerable, and face persistent persecution at the hands of their new neighbours, some of whom they replaced as Leghari's tenants. There are reports of sexual harassment of Bheel women working in the fields, aerial firing, and beatings of men, aimed at forcing them to leave their tenancy. The Bheels need to cross Omar's fields in order to access nearby markets and he often prevents them from using this direct route. The nearest school which is in OW is now barred to their children. A recent poverty survey bypassed the Bheel settlement on the grounds 
that it was makeshift and temporary. A mobile NADRA $^{8}$ team issued identity cards to a few of the Bheel men but recorded an adjacent village as their residential address.

The most dramatic story with respect to social marginalisation and residential security in our fieldwork in Sindh was with respect to GM in Deh Mori. The village was inhabited by a dozen or so families belonging to the Machhi caste which was traditionally marginalised but has seen upward mobility. The Machhis of GM were share-cropping tenants of absentee landlords and had become active members of the PPP from the 1970s onward. They had taken part in local campaigns against absentee landlords and for the implementation of tenancy regulations. In the 1980s the movement against absentee landlords became stronger and forced the landlords to concede ground to the tenants. In the 1990s the Machhi lobbied successfully with their party members who were now in government, for various facilities such as a government school. These facilities were awarded to them despite the fact that the village was actually settled on land which was privately owned by the landlords. Around this time, the absentee landlord sold his holdings to Ismail Sanjrani (a close relative of Iqbal Sanjrani), who used his own political connections and immediately began to counter the Machhis.

The conflict reached its climax in 1996, when soon after the dismissal of a PPP government, Ismail Sanjrani succeeded in mobilising the local police to forcibly evict the Machhis from their village. The village was razed to the ground and its only remnant was the abandoned school building which stood alone in the fields. The Machhis were scattered in different directions, and the leading family among them took refuge with an influential landlord who was a PPP leader. As a postscript, the return of the PPP to power in 2008 also saw the re-emergence and regrouping of the Machhis, who organised a public arbitration meeting with the Sanjranis, in which the latter accepted responsibility for the eviction and agreed to pay some compensation.

\subsection{Deh Kathi}

Deh Kathi is in the same district as Deh Mori, with similar economic conditions. The 1998 Population Census recorded 3,766 residents. There are 15 distinct settlements of various sizes in the deh. The largest is Jabal Talhani (JT), which is located close to a main road, and has 126 households.

Five out of the six para in JT belong to the Khaskhelis. The Khaskhelis are thought to be descendents of slaves and home servants of Sindh's pre-colonial ruling dynasty (Talpurs) and their close associates. They have been a historically marginalised group across the province, and near the bottom of the economic hierarchy in the landlord-tenant system. They are also a group, however, that has experienced upward social and economic mobility, in part through political engagement. Khaskhelis have sent legislators to the provincial assembly, and individuals from the group have attained professional qualifications and public standing. The sixth para is inhabited by one extended family of the Syed caste - which claims social status by tracing its lineage to the Prophet Mohammad.

The ownership of the land on which JT is located was contested between the local residents and a powerful landlord called Zahoor Bhambra who owns around 500 acres in the area. Most of the Khaskheli families of JT are share-croppers on Zahoor's land. Zahoor claimed that JT occupied land that was his private property. JT residents argued that the village was on state-owned bhadda land, but conceded that the cultivated land surrounding the village belonged to Zahoor. Zahoor's claim on the village land may be based on his invoking his customary right of mohaga.

There is a third version of this contest, according to which the village land was originally owned by Talpur landlords for whom the Khaskhelis used to work, and the Talpurs had awarded this land to the village for residential use as part of a verbal agreement. From the 1960s onward the Talpurs began selling their agricultural holdings around JT to the Bhambras. At the time, it was acknowledged that the village area - which was partly on bhadda and partly on privately owned Talpur land - would remain in the possession of the residents.

In the early 1960s, the Syeds of JT were the main activists. It was they who lobbied successfully for the establishment of a government school in their para and got one of their men appointed as the schoolmaster. The fact that the school was 
built in the Syed para provided a measure of official recognition to that part of the village. According to the Khaskhelis the establishment of the school led to tensions between them and the Syeds. They claim that Khaskheli children attending school would be taunted by Syed adults and children alike. By the 1980s, however, the Khaskhelis had acquired some political strength through the activities of some young men of the Talhani sub-caste who had acquired education. They now leveraged the numerical strength of the Khaskhelis to get the school shifted out of the Syed para and into the Khaskheli part of the village.

In 1988 the Syeds approached the SGAHS for the regularisation of the village. They used their connections in the land administration department and managed to get leases only for fellow-Syeds and their allies among the Khaskhelis. There was a flood in 1992 during which the entire population of the village was displaced. Some politically aware individuals among the Talhanis decided that they would stay back and maintain a presence on the site of the village, as it was feared that even temporary abandonment would encourage Zahoor Bhambra to reassert his claim over the land. At this stage, an NGO which had arrived in the area for flood relief involved itself in the village's land politics. The Talhanis suggested to the NGO that their first priority was to secure their rights over the land, and that any other relief or development work would be conditional upon attaining such security.

The NGO, which was already experienced in getting SGAHS implemented in other villages, now spearheaded the process of regularisation by engaging with the various stakeholders - the land administration department, the Bhambra landlords, descendents of former Talpur landowners, and political party activists and leaders. The entire village was regularised and all households received lease titles issued by SGAHS. Subsequent development interventions such as the lining of village lanes, a low-cost housing scheme, a drainage project and other physical infrastructure were also mediated by the NGO. These interventions were facilitated in part due to prior clarity over land ownership and the setting aside of land within the village for public purposes. The Talhanis, who emerged as the main local activists for the NGO, benefited disproportionately from these interventions.
One kilometre from JT there is a hamlet called Usman Zardari (UZ) consisting of around 35 families belonging to the Hindu Kolhi caste. The Kolhis - like the Bheels of Deh Mori above - are formally recognised as Scheduled Castes, and face the double disadvantage of religious minority and caste hierarchy. All families save one or two are share-cropping tenants of Usman Zardari, who is a major absentee landlord. The Kolhis between them farm some 97 acres, and have been in this position for the last 40 years. The land on which the village is settled is Usman Zardari's private property. All houses are made with makeshift material, although there is a small temple inside the village which is a brick and mortar construction. No children from the village go to school, and there are no public facilities or infrastructure available here. The Kolhis say that they have not applied for any facilities because they are aware that they live on somebody else's private property, and could be asked to move on at short notice. They claimed to have no knowledge of SGAHS or any other government scheme for village regularisation. There has not been any NGO intervention in the village, although the BISP poverty survey enumeration did take place here.

\section{Inclusion, exclusion and mobility}

The two dehs represent a remarkable range of processes and outcomes concerning SGHAS's interaction with the poor and socially marginalised. Even though the scheme was relatively dormant in Sanghar district - and the last case of scheme intervention in the fieldwork sites dated back to the mid-1990s - there was strong retrospective recognition of its effects. The largest group of beneficiaries in the fieldwork sites were residents of the two main bhadd $a$ villages - MV and JT. They were, clearly, intended beneficiaries, as they included mostly landless tenants who had been involved in dependent relations with big landlords. The Duzkanis of MV and the Talhanis of JT were from historically marginalised groups who experienced upward mobility through political participation. Although the precise nature of their interaction with SGAHS varied, mobilisation on the issue of land did play a role in fostering intra-group collective action, and indeed, in the formation of the group itself.

Other scheme beneficiaries included the nonDuzkani and non-Talhani landless poor of MV and 
JT, respectively. In some ways, these households were the unintended beneficiaries of Duzkani and Talhani mobilisation. The Bheels of MV and the Khaskhelis of JT who gained ownership rights to their homesteads on the bhadda were better off in material and political terms compared with the Bheels and Khaskhelis in the same region who were not on regularised land.

The SGAHS had provided virtually no benefits to people belonging to the most vulnerable categories in the survey sites: namely the Bheels of OW, and the Kolhis of UZ. Despite the fact the scheme was present in nearby villages, powerful landlords such as OW and UZ were able to ignore it without consequence. There were glaring exclusions of different types in these two cases. The Bheels of OW were actually entitled to legal protection, given that the village was located on state-owned bhadda land. The failure of the SAGHS to protect them, and their inability to even access the scheme was a stark indictment of the project. UZ represented a case where the scheme failed, despite the presence of an active NGO in the close vicinity. The reliance on prior collective action by potential beneficiaries created insurmountable barriers for these groups.

The case of the Machhis of Deh Mori and their eviction at the hands of Sanjrani landlords can also be interpreted at one level as the failure of the SGAHS. In truth the story is more complex. At a particular moment in time, the historically marginalised Machhis differed little from the Duzkanis and the Talhanis in terms of their upward mobility and their rising access to political networks. Their inability to gain secure rights of possession and ownership over their homesteads was probably due to the fact that their village was on land privately owned by the Sanjranis. There is little doubt that legal title in the form of an SGAHS lease helped the Duzkanis to resist the Sanjranis in MV, and the absence of legal title meant that the Machhis' resistance collapsed at a moment when they were political vulnerable.

The SGAHS process and lease appears to have helped the intermediate groups who were properly entitled to scheme benefits, but not the most marginalised groups who needed greatest support. The test of a truly transformative intervention will be its ability to enfranchise the most marginalised - in this case, the Bheel,
Kolhi, Ibupota and Khaskheli landless tenants and labourers. The verdict from our fieldwork sites is nuanced. There were obvious manifestations of landlord power over homestead land, but also examples of enforced restraint. The most marginalised remained highly vulnerable, although some of those who now appear as intermediate groups had previously been counted among the most marginalised.

The fieldwork in Sanghar district was opportune because this happened to be one of the three districts in Sindh where a poverty census for registering and identifying the beneficiaries of the BISP was carried out in 2009. It was possible to observe the patterns of inclusion and exclusion in the BISP poverty census in the survey sites. There were two conspicuous cases of exclusion: Bheel tenants displaced from OW, and a group of Bagri seasonal migrants camped close to FT. The latter are widely regarded as a peripatetic community, and are often excluded from formal entitlements on the grounds that they have no fixed abode. All other residents of the two survey sites, including those who lived on landlords' privately owned land, such as the Kolhis of UZ, were enumerated at their place of actual residence. The administrative 'census method' of the BISP, therefore, overcame many more dimensions of social marginalisation than SGAHS. People left out of the BISP census, nevertheless, happened to be precisely those whose residential status at a particular location was subject to some doubt - which in turn was a function of prior residential insecurity.

\section{Conclusion}

Contests over residential land were far more pervasive than suggested by secondary data, which records a high prevalence of private ownership. They also took many shapes and dimensions including physical security, access to basic citizenship-based entitlements, and economic autonomy. Social marginalisation was almost always closely linked to differing local rights and privileges relating to homesteads and other residential and social uses of land.

In communities where informal arrangements for accessing resources were important, there were two sets of implications of a government scheme which did not pay specific attention to local social structures. One was the unintentional subversion of an existing customary privilege (in this case 
mohaga) which favours incumbent property owners at the expense of socially and economically marginalised groups.

The relatively socially neutral language of 'a deserving person in genuine need of accommodation' was invariably interpreted on the ground in terms of local contests between castes and kinship groups over status, economic resources and political power. Scheme beneficiaries included many individuals, families and groups who belonged to historically marginalised communities. For many of them, upward mobility was an ongoing and non-linear process and struggle in which the existence of the scheme provided a helping hand. In some cases, the scheme acted as a catalyst for effective mobilisation which then delivered significant gains. Even those who were inattentive to the potential benefits offered them by the scheme at its outset became aware of its advantages once their dispute with other local players became active.

The SGAHS helped to strengthen collective action on the part of some socially marginalised groups. The main lines of mobilisation, however, were around patriarchal kinship group and tribe. The scheme's most serious limitation was its inability to reach out to those who were too weak to even contemplate collective action in pursuit of citizenship-based entitlements. The dormancy of the scheme was yet another indicator that the social capital required for effective demand mobilisation was weaker than the ability of landlords to assert their claims.

This article has also found that the effectiveness of social protection or redistributive interventions cannot be extracted from the general level of political violence in society at large. Rural Sindh is not alone in Pakistan, South Asia, or indeed
Asia as a region with unequal class relations, and active contestation between groups over resources. In such unequal societies, state action often protects incumbents against challengers from below, but laws and interventions explicitly directed toward the marginalised can trigger positive political responses or act as focal points for existing mobilisations.

The idea that the one-off regularisation of land ownership and possession or even the transfer of state-owned land is more fiscally sustainable than continuous cash transfers needs qualification. Fiscal sustainability is a function of the ability of the government to effect the redistribution of income. Although land allotment and regularisation seems like a cost-free transfer from the state to the poorest, in actual fact it can represent a more direct and intense redistributive conflict at the local level. This is because weak property rights among the marginalised invariably imply prior stakes in land on the part of the dominant groups, regardless of whether or not the land is nominally owned by the state.

Finally, the limitations of the SGAHS do not imply that interventions that require and then reward prior collective action have no relevance in class-unequal societies such as rural Sindh. Social protection measures such as cash transfers which administratively identify poor beneficiaries (e.g. the BISP) will have greater success in reaching out to the most marginalised than demand-driven interventions. But such 'passive' transfers will not become part of the political mobilisation strategy of upwardly mobile marginalised groups in the way that SGAHS has done in many instances. There is room and need for both types of interventions, and the lessons of SGAHS become particularly pertinent when there is policy interest in the transfer of government land. 


\section{Notes}

1 India's National Rural Employment Guarantee, examined in two separate contributions to this volume, has elements of prior collective action on the part of potential beneficiaries.

2 SGAHS: Sindh Goth-Abad (Housing Scheme) Act, 1987.

3 Authors' calculations based on Agricultural Census 2000, and Population Census 1998.

4 Pakistan Peoples Party.

5 Land reform measures in the 1970s included land ceiling revisions in 1972 and 1977, and pro-tenant amendments to tenancy regulation

\section{References}

Devereux, Stephen and Sabates-Wheeler, Rachel (2004) Transformative Social Protection, IDS Working Paper 232, Brighton: IDS, www.ids.ac.uk/ids/bookshop/wp/wp232.pdf (accessed 1 December 2008)

Kabeer, Naila (2005) 'Introduction', in Naila Kabeer (ed.), The Search for Inclusive Citizenship: Meanings and Expressions in an Interconnected World, New York: Zed Books Limited

Kabeer, Naila (2002) Gitizenship and the Boundaries of the Acknowledged Community: Identity, Affiliation laws. These legal interventions encouraged tenants in many parts of the province to confront landlords over crop shares and other entitlements. Land reform legislation and implementation have remained suspended since the 1980 s after a court ruling that such laws were anti-Islamic.

6 One of the authors took part in meetings with the Sindh provincial government in 2008 to discuss the possibility for reviving the SGAHS.

7 Benazir Income Support Programme is the flagship cash transfer programme of the federal government.

8 National Database and Registration Authority.

and Exclusion, IDS Working Paper 171, Brighton: IDS, www.ntd.co.uk/idsbookshop/ details.asp?id=715 (accessed 4 March 2010)

Olson, Mancur (1971) The Logic of Collective Action: Public Goods and the Theory of Groups, Cambridge, MA: Harvard University Press

Sharma, S.L. (1992) 'Social Action Groups as Harbingers of Silent Revolution', Economic and Political Weekly 27.47: 2557-61, www.jstor.org/ stable/4399156 (accessed 13 January 2009) 